\title{
Performed Product Transport
}

National Cancer Institute

\section{Source}

National Cancer Institute. Performed Product Transport. NCI Thesaurus. Code C95398.

The completed action for a product transportation event. 